\title{
A 21st CENTURY SECURITY ARCHITECTURE FOR THE AMERICAS: MULTILATERAL COOPERATION, LIBERAL PEACE, AND SOFT POWER
}

Joseph R. Núñez

August 2002 